\title{
Beyond Bureaucracy-Public Administration as Political Integrator and Non-Weberian Thought in Germany
}

\begin{abstract}
The political role of public administration holds an ambiguous status in public administration theory. The dominant paradigms of the discipline offer more or less negative perspectives. Max Weber's notion of bureaucracy conceives public administration as the apolitical tool of government, while the public choice school conceives it as the realm of individual selfishness and rent seeking at taxpayers' expense. In this unfavorable epistemological environment, positive concepts of what makes public administration "political" can hardly flourish. However, as public authorities may organize
\end{abstract} clientele participation and consequently co-opt stakeholders, they provide for symbolic sense making and create patterns of identity. Public administration thus works as a political integrator in its own right. Unfortunately, this subject is not prominent within contemporary scholarly research. German political integration through administration is analyzed here in order to address these and related theoretical questions.
While Weber's notion of public administration as "bureaucracy" may appear underpoliticized, public administration presents itself as an overpoliticized phenomenon in the public choice perspective. Viewed through these lenses, the pressing issues of public administration are those of performance and control for the sake of accountability and policy outcome improvement. It is about principal-agent problems, performance measurement, organizational learning, and public management. This obviously

shapes the perception patterns and research agendas of scholars in the field. The political role of public administration is unevenly represented in mainstream public administration theory and research. Issues of governance and administrative performance are overrepresented, while issues of civil rights protection or political integration, for instance, play a minor role.

In this unfavorable epistemological environment, positive $\mathrm{T}$ The political role of public administration holds an ambiguous status in public administration theory. The dominant paradigms of the discipline give a more or less negative account. Max Weber's notion of bureaucracy conceives public administration as the apolitical tool of government. It is, in his conception, the "purely bureaucratic, thus bureaucratic-monocratic, document-based administration" that guarantees "the highest degree of performance" as the "formally most rational type of authority" (Weber 1922, 128). The contending paradigm, the public choice or economics of bureaucracy school (Downs 1967; Niskanen 1971), conceives it as the realm of individual selfishness and rent seeking at taxpayer's expense under the veil of information asymmetries and infested by principal-agent pathologies. 
Public administration as a political integrator does have its theoretical points of reference, but they are scattered and not necessarily related to the public realm. Chester Barnard, Herbert A. Simon, Philip Selznick, and J. Donald Kingsley in various ways emphasized the role of formal organization as an integrative phenomenon. Focusing on the balance of inducements and contributions (Barnard, Simon), on the prerequisites of individual commitment to organizational goals (Selznick), or on the representative function of bureaucracy (Kingsley), these authors stress the mutual dependence of organizational cohesion and integrative capacity. With the exception of Selznick, however, the influence of these schools of thought remained limited or unfolded in the research on business administration.

It is here that the German tradition of public administration thought is different, precisely because the history of German public administration is different. Public administration in Germany served as a political integrator long before parties and parliaments emerged. It was even conceived as such as an alternative to constitutional government in the early nineteenth century (cf. Koselleck 1967). The irony is that, while students of public administration around the world will identify the German contribution to the field in the work of Max Weber, the science of public administration in Germany is much more influenced by non-Weberian thought, which explicitly addresses the very political role of bureaucracy that Weber either neglected or rejected.

The present paper is devoted to this non-Weberian thought in German administrative science and its contribution to a positive theory of political integration. Its message is that a particular trajectory of political and administrative modernization made nonWeberian thought heavily influential in shaping the notion of public administration in Germany. Lorenz von Stein, Otto Hintze, and Rudolf Smend are portrayed as Weber's most important contenders. Their work became important precisely because it was better adapted to the peculiarities of political and administrative modernization than Weber's ideal-typical concept of bureaucracy.

- Lorenz von Stein (1815-90) portrayed public administration as the "working state," a living organism instead of just a tool of government, thus laying the groundwork for conceiving the state apparatus as a socially embedded entity.

- Otto Hintze (1861-1940) gave the most exhaustive empirical analysis of the integrative role of public administration when characterizing the co-optation of the landed aristocracy into the Crown's army and administration as a prerequisite of stable government in early modern Germany.

- Rudolf Smend (1882-1975), finally, addressed the entire machinery of government as an integrative mechanism emphasizing, among other things, the mutual adjustment of administrative decision making and what he termed the "spirit of the public" (Geist des Publikums).

Stein, Hintze, and Smend, therefore, cover both structural and ideational elements of political integration through public administration. This is what makes their work important not just for an appropriate understanding of the peculiarities of the political and organizational modernization of government in Germany, but also for the political role of public administration in general.

\section{The German Pattern: Integrating Challenging Groups through Public Administration}

While it is commonplace that the history of German government and administration was shaped by territorial fragmentation, the countermovement of administrative modernization has not attracted very much attention among historians, let alone students of public administration. Driven by the necessity of organizing and financing standing armies after the traumatic experience with the devastating effects of mercenary armies during the Thirty Years' War, professional bureaucracies emerged in key states of Germany from the late seventeenth century on. Full implementation of constitutionalism, however, was substantially delayed compared to the United States and to Great Britain and France, the two most politically and economically advanced countries in Europe.

The basis of this development was a combination of administrative efficiency and the integration of challenging societal groups. The prerequisite for a standing army was the loyalty of the aristocracy. Standing armies of the Crown were the natural enemy of the landed aristocracy all over Europe. In France and England, the conflict was solved violently, with either the Crown wielding absolute power over the expenses of the aristocracy (France) or parliament acting as the arbiter to balance the power of the Crown and the nobility (England). In Russia, the tsars guaranteed the ownership role of the landed nobility while stripping the latter of its local political power.

What characterized this situation in Germany-Prussia in particular-was a peaceful compromise between the Crown and the landed nobility, with the latter keeping both landownership and local political and administrative power while conceding to the Crown the exclusive right to run a standing army and to levy taxes to finance it. Officer ranks were manned by the sons of the landed aristocracy, typically the younger ones who were not entitled to inherit the estate. This arrangement guaranteed that the army would not be used to oppress the nobility while securing the loyalty of the latter to the Crown. It also enabled the landed aristocracy to keep expanded estates intact, as male heirs were not forced to partition the property. Rather, the co-optation of the landed aristocracy into the army elevated the prestige of the armed forces while enabling aristocrats who were not entitled to inherit to keep an elevated social status and an influential role in running the Crown's government. The system also had a positive impact on agricultural productivity, as cultivated ground was not unnecessarily compartmentalized, which, in turn, strengthened the economic basis of the military and its administrative infrastructure.

Moreover, the landed aristocracy remained in charge of local administration. This was known as "patrimonial rule" (Patrimonialgewalt), which encompassed the responsibility of the head of the local noble family for the entire range of administrative affairs, including the appointment of priests. In the eastern provinces of Prussia, the head of county administration (Landrat) was a member of the local nobility until 1918 or even until 1945. The Landrat was a representative 
of the Crown and of local self-administration at the same time. The Crown's authority in its pure form, however, stopped at the regional level of the district administration (Regierungsbezirk) with a district commissioner (Regierungspräsident) at its top. Until 1918, the Regierungspräsident, too, was a member of the nobility. Thus, the landed aristocracy as a potentially challenging group opposing the Crown was firmly integrated into the Crown's administrative machinery.

What was initiated as a compromise between the Crown and the landed nobility in the seventeenth century turned into a combination of central and local administration, based on professional bureaucracy as its backbone, that has shaped the structure of German public administration until today. This is of obvious importance when it comes to an appropriate understanding of how German public administration works and how its political and organizational qualities have been reflected in German administrative science. Organizationally, the system combined the strength of hierarchical coordination through the central authority of the Crown with the adaptability of local self-administration. Politically, it established an equilibrium between the central authority of the state and the main challenging group at the time, the landed nobility (cf. Skocpol $1979,99-112$, for an account especially on the counterrevolutionary effect in Prussia).

The use of public administration as a political integrator has remained a crucial feature of German public administration until the present day, with a proven record of adaptability throughout several phases of emerging challenging groups and state response. Once established as the organizational form of compromise between the Crown and the landed nobility, this pattern was also instrumental in integrating the emerging class of the bourgeoisie from the early nineteenth century on, and it even helped mitigate the conflict between the authoritarian state and the working class that emerged at the end of the nineteenth century. The emphasis on peripheral adaptability and self-administration established a framework that shielded the core of the state against various challenges. To a considerable extent, this explains the resilience with which German statehood responded not only to fundamental domestic opposition, but also to phases of total political breakdown at the brink of ultimate disintegration in the twentieth century (cf. Seibel 1996).

\section{Hegel's and Weber's Notions of State and Bureaucracy: Inappropriate and Functional at the Same Time}

Ironically, the very structural strength of German government and administration, based on its integrative capacity and local adaptability, was not reflected in the most prominent and influential conceptualizations of modern statehood: Hegel's theory of the state and Weber's theory of bureaucracy. Hegel did not use the word "bureaucracy," but he conceived the state, and thus government and administration, as the incarnation of reason as long as it justly applied the law and as long the individual members of the governmental apparatus - read: the bureaucrats-were committed to that universal idea (Hegel 1821, 406-512). This corresponded to Weber's concept of bureaucracy as the

materialization of the rule of law. Both Hegel and Weber made the legitimacy of state power a focal point of their theories. ${ }^{1}$ However, Hegel connected legitimate state power to the abstract notion of the representation of a universal common good, while Weber focused on the legitimizing effect of formal legality. To that extent, both Hegel and Weber were representatives of the "rationalist" school of thought in public administration, which neglected the "organicist" perspective on the state as an organizational phenomenon (cf. Waldo 1961). Accordingly, the actual quality of German public administration in achieving not only organizational effectiveness and coherence but also the political integration of challenging societal groups was beyond their theoretical grasp.

However, Hegel's notion of the state as the epitome of reason provided a blueprint for a reintegrative myth: precisely because the structure of German government and administration was strongly decentralized and designed to enhance local adaptability as well as micropolitical integration, a unifying idea of the nation-state, based on reason and the rule of law, was an important countervailing factor. As Christopher Clark pointed out in his seminal study on the "Iron Kingdom" (Prussia), it was the "apotheosis of the state" (2006, 427-35) that made Hegel's theory so well suited to the characteristics of a decentralized and territorially dispersed state structure. Hegel's theory of the state reminded civil servants to give their best for the sake of the state as the true representative of both reason and a quasi-religious commitment to the unselfish fulfillments of duty. Moreover, Hegel's theory was based on the idea that the state was embedded in civil society and, indeed, was the prime representative of the ethical substance of the people as citizens. This, in turn, reminded the dominant aristocracy of their duty in terms of loyalty while at the same time legitimating their power and influence. Thus, Hegel's theory was characteristically ambivalent, as it contained both progressive and conservative elements as far as the relationship between citizens, civil service, the state, public administration, and civil society was concerned.

Hegel's notion of the state, however, remained abstract in the sense that neither the actual organization of government and administration in the German territories nor the nature of the bureaucratic organization as such became part of it. Weber's theory of modern bureaucracy, by contrast, did focus on the organizational nature of the state, but it did not pay attention to the empirical variance of bureaucracy and how it was linked to political integration.

Instead, Weber's interest focused on the inherent logic of an idealtypical organization called "bureaucracy" that was not connected to the actual develop-

Ironically, the very structural strength of German government and administration, based on its integrative capacity and local adaptability, was not reflected in the most prominent and influential conceptualization of modern statehood: Hegel's theory of the state and Weber's theory of bureaucracy. ment of German public administration. That logic, according to Weber, was based on the rationalization of power in the double sense of formal legitimacy of political rule and the effective implementation of the legitimate will of the rulers. What became known as the typical elements of bureaucratic organization-hierarchy, legality, professionalism, fixed monetary salaries, lifelong appointment of civil servants, separation of office and person, fixed division of labor, written rules, and written communication-was connected to 
two basic ideas: that "bureaucracy" is a type of authority ${ }^{2}$ and that it is the most efficient and effective variant of authority. ${ }^{3}$ This was a nonempirical, ideal-typical concept (cf. Mayntz 1965) that did not contain the slightest reference to the actual relevance of bureaucracy for the organization of public authority in recent German history.

As a consequence, prominent and vividly debated as it was in German academia, Weber's notion of bureaucracy had no particular impact on doctrine building in German administrative science. We may assume that the main reason for Weber's limited practical influence was the gap between his ideal-typical characterization of bureaucracy and the way in which public administration in Germany actually organized both legitimate authority and societal integration. "Bureaucracy" in Weber's sense was profoundly apolitical. It was just executing the political will of those in power on a legal basis. This was more or less the opposite of the actual role of public administration as a political integrator that characterized the German condition.

\section{Weber's Contenders: Lorenz von Stein, Otto Hintze, and Rudolf Smend}

Much closer to the role of public administration as a political integrator is the work of Lorenz von Stein (1815-90), Weber's most prominent contender in the history of related ideas. The reception of Lorenz von Stein and the widespread reference to him in German administrative science is characterized by some bizarre peculiarities, though. First, the Vienna-based professor of law Lorenz Stein, ennobled in 1868 as Lorenz von Stein, is often mistaken, even in Germany and Austria, for Heinrich Friedrich Karl vom und zum Stein (1757-1831), the Prussian minister and mastermind of administrative reform in Prussia in the early nineteenth century. Second, the frequency with which Von Stein is cited as one of the founding fathers of modern German administrative science stands in stark contrast to the paucity of his actual conception on public administration. Third, and tellingly, the vast majority of scholars who praise Lorenz von Stein and his understanding of public administration refer to a single notion, the "working state" (arbeitender Staat). Just as Hegel's notion of the state as the actual materialization of reason served as a reintegrative myth that was helpful for organizing the coherence of a decentralized and territorially dispersed administrative structure, Lorenz von Stein's notion of the working state serves as the keyword of non-Weberian rhetoric in German administrative science. In the absence of a coherent theory of the working state, however, many students of public administration, Germans in particular, have ascribed to that notion almost any property of public administration that is not strictly and directly connected to its formal and legal side.

Vague as it was from the very outset and blurry as it became in the course of its reception in administrative science literature, Von Stein's notion of the working state has a rational core. In his most influential monograph, Verwaltungslehre und Verwaltungsrecht (Administrative Science and Administrative Law, 1865), Von Stein refers to Hegel's notion of the juristic personality (Rechtspersönlichkeit) of the state. He maintains that taking that personality seriously implies taking the actual life of the personality of the state seriously as well. And just as the actual life of an actual person, the actual life of the state is characterized by the distinction of deed and work (Von Stein 1865, 21-26, "Der organische Begriff der Verwaltung"
[The Organic Notion of Administration]). The problem with mere deeds, according to Von Stein, is that the state (read: government) typically fulfills a "deed" in the form of issuing a law, pronouncing an indictment, or making another type of decision. But the state is unable to lead an actual life merely on the basis of a series of individual decisions. Just as the actual life of a person is based on executing decisions in the form of work, the actual life of the state, according to Von Stein, is based on administration. Thus, administration is the actual life of the state as a working state $(1865,24)$.

It is easy to comprehend why the metaphor of the working state became attractive for students of public administration, especially in the German-speaking scholarly community. In the writings of Lorenz von Stein, the Hegelian state appeared not just as an abstract principle, but as a living reality termed "administration" (Verwaltung). For those engaged in empirical research on German public administration, this was and still is a more influential concept of administration than Weber's ideal-typical notion of bureaucracy. While it would be an exaggeration to speak of two schools of thought in German administrative science-one following Lorenz von Stein's idea of the working state and the other following Weber's concept of bureaucracy-German scholars in various disciplines who define themselves as "administrative scientists" (Verwaltungswissenschaftler) do this principally with reference to Lorenz von Stein rather than to Weber.

Inherent in this was always the risk of a benevolent overinterpretation of Lorenz von Stein and his actual contribution to the understanding of public administration. ${ }^{4}$ It certainly did not provide any enduring theoretical stimulation other than the intelligible metaphor of the "working state." Lorenz von Stein left us with an eight-volume Handbook of Administrative Science (Handbuch der Verwaltungslehre), which contained the essence of good practice recommendations for the entire variety of public administration domains that turned out to be obsolete by the time the opulent series was finally published (1866-84). Von Stein enthusiasts pointed to his understanding of state and society as mutually penetrating phenomena (cf. Blasius and Pankoke 1977; Scheuner 1977). However, this remained a vague concept. Lorenz von Stein, also a learned student of socialist and communist movements in France, was remarkably negligent regarding the social forces that had formed the actual shape of German public administration since the seventeenth century. The career of the metaphor of the working state, however, remained unaffected by the theoretical and empirical insensitivity of its creator.

Paradoxically, the scholar who significantly shaped our understanding of German public administration and its political-sociological embeddedness is much less known than Lorenz von Stein, even in Germany, despite the tremendous richness of his empirical observations on German government and administration in early modern history. The historian Otto Hintze (1861-1940) did not coin any prominent notion of statehood or administration, nor did he develop a school of thought comparable to that of the famous German historians of the nineteenth century, such as Leopold von Ranke, Theodor Mommsen, or Heinrich Treitschke. However, what we know about both the formation of public administration in modern German history and its political and societal embeddedness we know largely through the work of Otto Hintze. There is hardly 
any other prominent scholar in the humanities in Germany since the mid-nineteenth century, including Max Weber, whose work is even remotely as extensively devoted to public administration and the emergence of modern bureaucracy as the work of Otto Hintze. In a way, Hintze is Weber's counterpart in the field of administrative science as historical sociology (cf. Kocka 1981; a collection of relevant papers of Otto Hintze's in English is made available in Gilbert 1975; a brief account of his work can be found in Page 1990).

According to Hintze's interpretation, public administration was the original mediator between state and society. This was clearly a Hegelian and Von Stein perspective. However, in his empirical research, Hintze was deeply penetrating the actual reality of the state-society relationship in the realm of public administration, often with Prussia as the paradigmatic case. Unlike Weber, he emphasized the political role of public administration, especially the political role of the upper levels of the civil service (Hintze 1911). He praised the notion of sober professional judgment and political sensibility that, in his perception, characterized the high standard of the ministerial bureaucracy in Germany and its career patterns. This made him reject the idea of parliamentarian government as a threat to professional administration under the particular German circumstances, an attitude that he changed during the course of World War I.

Like the work of Lorenz von Stein, that of Otto Hintze is characterized by some contradictions and paradoxes. His earlier work proved to be more original and distinctive, especially when compared to Weber, relative to what he published after the end of World War I. He could not imagine that public administration could sustain its political role in a nonelitist environment of democracy and parliamentarian government (a striking parallel to the influential writing of the much younger Carl Schmitt), nor was he inclined to expand the notion of the integrative function of administration beyond the threshold that separated the monarchic regime upheld in Prussia and the rest of Germany until 1918 from parliamentarian democracy as it was established with the constitution of Weimar in August 1919. Hintze's work in the 1920s and 1930s became, as Kocka (1981) noted, more and more similar to that of Max Weber, to the extent that he accepted the idea of bureaucracy as a merely technical instrument whose organizational efficiency would make up for the potentially detrimental influence of parliamentarianism. This was, indeed, a sort of Schmittian contribution to administrative science.

The earlier Hintze, however, was innovative and remarkably "modern" in a double sense. He described the potential of public administration for political integration, and he was advocating a more flexible and adaptable sort of "boundary spanning" between the public and the private sector.

In a series of pre-1914 articles, Hintze invoked the adaptability of public administration in Prussia during the eighteenth century with respect to the particular interests and the resistance of the landed nobility (Hintze 1896, 1906, 1908, 1913, 1915). He described the gradual replacement of foreigners in favor of the indigenous nobility within the immediate court administration, starting in the midsixteenth century, and the admission of educated bourgeois civil servants to the upper ranks of state administration, especially in the provinces, and the role of decentralized authorities at the regional level as a sort of buffer zone between the Crown the landed estates, mediating between antagonistic interests and securing overall coherence of the state apparatus at the same time. Hintze also gave an account of the gradual containment of the quasi-parliamentary institutions that represented the landed nobility, the Landtage, through central regulation by the Crown and an increasingly detailed reporting system (cf. Ertman 1997). Dispersed as Hintze's papers were during his lifetime, they nonetheless provided a multifaceted picture of the "organic" nature of public administration, its societal embeddedness, and its potential for political integration.

Another aspect that gained prominence in Hintze's work after 1900 (cf. Hintze 1911, 1927) was his acknowledgment of the positive impact of the economic activity of government agencies and, in today's language, the hybridization of public and private institutions. Modern or even "socialist" as it may sound, these ideas were firmly grounded in Hintze's research on the stimulating role of governmental activity and administrative reform, again especially in Prussia, during the seventeenth and eighteenth centuries. Now, in the last phase of the dramatically accelerated process of industrialization in imperial Germany before World War I, Hintze analyzed the mutual penetration of public administration and private business - for instance, in the armaments industry - and the importance of public enterprises at the municipal level and advocated a flexible handling of the civil service statutes and the careful introduction of some elements and principles of business administration into public bureaucracy.

This may suffice for an illustration of how empirically saturated and both analytically and conceptually original and innovative Hintze was precisely where his work diverged from Weber's ideal-typical and normative notion of the bureaucratic state and its supposed separation from politics and society.

However, as we have seen, Hintze had difficulty adapting his lucid conception of the political role of public administration and its societal embeddedness to the postmonarchical era. To him, the quasi-political role of German public administration was a compensation for the absence of parliamentarianism as the genuine form of political modernization in Western Europe already during the nineteenth century. With parliamentary government established in Germany in 1918, the political role of public administration, its integrative function in particular, seemed less desirable. While the left had good reasons to assume that, from a democratic and constitutional perspective, any interference of the civil service with political affairs would violate the legitimate monopoly of power residing with parliament and elected officials, conservatives, in a surprisingly similar vein, defined the apolitical status of public administration as the core of a robust state apparatus that protected government against the repercussions of political instability. Neither the leftist nor the conservative perspective allowed for the notion of an actively integrating state apparatus that was loyal to the newly established democratic constitutional order. The result was a widening gap between what the democratic order required and what the main political forces were willing to concede to public administration as a political integrator.

Theoretically, this gap was partly filled by Rudolf Smend (18821975) and his "integration doctrine" (Integrationslehre) (Smend 
1923, 1928). Smend's basic idea was that the strength of the constitution was based on its integrative capacity and that political integration was a multifaceted phenomenon far beyond the formal order of the constitution and conventional mechanisms and institutions such as parties and parliaments. What was, above all, positive was that Smend made the notion of integration prominent at all in a time of deep and, as it soon would turn out, self-destructive political divisions and potentially violent conflicts in Germany. This is what made his ideas acceptable to the thin democratic segment of public law scholars and public intellectuals in the last and lethal phase of the Weimar Republic. The flip side was the justification of mechanisms of political integration outside the written constitutional order. This implied arbitrariness and the opposite of transparency, responsibility and accountability as core elements of democratic constitutionalism. Not a single section of Smend's main book, Verfassung und Verfassungsrecht (Constitution and Constitutional Law, 1928) was devoted to democracy or democratic constitutionalism. Instead, he mentioned without further qualification Italian fascism as an instructive example for one out of three core mechanisms of integration, namely, integration through personality and leadership (Smend 1928, 23). ${ }^{5}$

However, Smend explicitly included public administration in his list of integrative elements $(1928,30-31)$. He provided the "missing link" that was absent in the conceptual framework of Weber and Hintze as far as the integrative role of public administration was concerned in characterizing the function of the civil servant as susceptible to what he called the "spirit of the public" (Geist des Publikums) $(1928,30)$. In a distinctly antipositivist way, Smend argued against legal formalism in the application of the law by the individual civil servant. He pleaded for a civil service that would take into account what is acceptable and legitimate in the eyes of the overall public. This was a definite alternative to Weber's view of bureaucracy as being apolitical as well as uncharismatic and purely formalistic by its very nature. What is more, Smend implicitly stressed the importance of the psychological sensitivity of the individual bureaucrat for the undercurrents of public opinion, a point clearly neglected in the work of Weber and Hintze alike.

Democratic or progressive as the ideas of Rudolf Smend may sound today, they were designed to justify all kinds of political ideology influencing the practice of public administration under the formal auspices of the rule of law. It was precisely the acceptability of political ideology in the guise of the "sound sentiment of the people" (gesundes Volksempfinden) that shaped the practice of public administration under the Nazi regime while maintaining the illusion of a perpetuated rule of law. ${ }^{6}$ Rudolf Smend was not a Nazi himself, nor did his "integration doctrine" gain direct and substantial influence during the Nazi period from 1933 to 1945 . But the idea of public administration as executing the rule of law in accordance with criteria of conventional wisdom or common sense was to some extent compatible with the ideology and practice of Nazi rule, to the extent that it encouraged public officials to act in accordance with the Nazi worldview (nationalsozialistische Weltanschauung) rather than with the binding stipulation of the law.
Smend's integration doctrine was undoubtedly well suited to justify the role of public administration as a relatively independent power center at the expense of parliament and elected officials. In the Smendian school of thought, public administration was the locus of independent state power (Peters 1965), only loosely bounded by the law but committed to the cause of the common good (cf. Badura 1977; Ehmke 1960; Herzog 1970; Martens et al. 1972; Ossenbühl 1978). These ideas became particularly influential in post-World War II West German jurisprudence and beyond (Lhotta 2005). ${ }^{8}$ One more time, their intellectual appeal resulted from conceptual elasticity: the notion of public administration as committed to the common good and serving as an integrative force of its own right could be interpreted as both a conservative justification of robust statehood and a stabilizing element in times of political crisis as well as a liberal defense of the public interest against the abuse of governmental power.

\section{Structural Transmitters}

As it has been stated in a different context, "ideas do not float freely" (Risse-Kappen 1994). What made non-Weberian thought so influential in German public administration was the complementarity of ideas and structural transmitters. The deviations from the abstract notion of public bureaucracy, Weberian style, did not only occur in purely theoretical terms; rather, they were practically implemented as alternatives to formal legality, organizational hierarchy, professionalism, and division of labor within the legal and organizational structure of German public administration. All of these elements were designed to enhance the flexibility and integrative capacity of public authorities.

Formal legality was softened through an increasing use of indefinite terms and general clauses in the post-World War I era (cf. Hedemann 1933). This was generally interpreted as a consequence of the intensified regulatory activity of the state at a time when industrialization and the emergence of the welfare state coincided. Indefinite legal terms and general clauses were meant as technical mechanisms of coping with regulatory complexity. They left discretionary leeway to public authorities working under the respective law, and thus conceded to public administration the very autonomy that, in a Smendian sense, is the prerequisite for an independent integrative function of bureaucracy. ${ }^{\circ}$ But they also served as a vehicle for ideational integration on the basis of the common sense that Smend euphemistically called the "spirit of the public," which, in practice, could easily become the pretext for submitting the rule law to the imperatives of political ideology (cf. Rüthers 1968; Stolleis 1974).

As far as alternatives to organizational hierarchy are concerned, the "corporation of public law" (Körperschaft des offentlichen Rechts) is the decisive component in the organizational dimension. The Körperschaft is defined as membership based. The idea is the co-optation of those using the respective corporation or participating in its activity into its governing bodies. This particular legal form of government agencies dates back to the early nineteenth century, at which time it was meant as an alternative to parliamentary government. Through co-opting selected representatives of 
society, the bourgeoisie in particular, the reformers of Germanread, again: Prussian - public administration attempted to ward off further-reaching pretensions to full democratization (cf. Koselleck 1967). "Administrative reform instead of constitutional reform" was the key slogan, and the creation of the corporation of public law was the key element of its operationalization. This came close to what, a century later, J. Donald Kingsley (1944) would call "representative bureaucracy," based on a balance of self-administration (Selbstverwaltung) and state control (Stadtsaufsicht).
The actual application of indefinite legal terms and general clauses as well as the discretion explicitly granted by the law in the form of Ermessen have been standardized through the public administration law literature and the rulings of the upper levels of the court system. What also works in favor of a substantiated rule of law is the constitutional guarantee of the right of the individual citizen to sue any governmental body before the local administrative courts (Article 19 of the Basic Law) and the fact that court fees in Germany are relatively low.
Another nonhierarchical component of German public administration - quite at odds with the image of an executive branch charged with the legacy of authoritarian regimes of various sorts-is the culture of cooperation and compromise as a crucial element of the state-economy relationship. While it is widely acknowledged that Germany falls into the category of neocorporatist government, it remained largely ignored that the state-society relationship follows a similar pattern in the administrative dimension. This, too, dates back to the compromises between the Crown and landed aristocracy in the seventeenth century.

One might say, however, that the shadow of Hegel and Weber was long enough to overshadow the strong tradition of cooperative public administration, whose strengths and virtues were (re)discovered in administrative science literature, even in Germany, only at the end of the twentieth century (cf. Benz 1994; Ellwein 1993; Lehmbruch 1987). To their own astonishment, scholars in the field of empirical implementation research, which emerged in the 1970 s, realized that local authorities were constantly negotiating with private enterprises on local standards of environmental protection (Mayntz 1983; Mayntz and Derlien 1978; Mayntz and Hucke 1978). This was not surprising at all, though, from the perspective of the history of German public administration law, with its extensive use of indefinite legal terms and general clauses designed to provide local administration with discretionary leeway for individually adapted solutions. At the time, it was nonetheless (mis)interpreted as a new posthierarchical style of administrative behavior (cf. Mayntz 1983).

Inherent in the flexible application of the law by local administration is the risk of arbitrariness, agency capture, or even corruption, and thus the corrosion of the rule of law as such. What mitigates that risk under the German conditions is a fairly balanced combination of jurisprudential doctrines on how to use the discretionary leeway granted by the law, on the one hand, and the delegated rights of self-regulation, on the other. The combination of these two mechanisms enables public administration at the regional and local levels to exert a certain amount of flexibility while at the same time developing the necessary degree of standardization and coherence in decision making.

Delegated self-regulation of public administration takes place in the form of subparliamentary legislation as ordinances (Verordnungen) and the charters of self-governing bodies, with the corporations of public law (Körperschaft des öffentlichen Rechts) as the typical case.
The flip side is represented by weak standards of due process in administrative decision making, which never gained strong recognition in Germany. Violation of procedural standards cannot be challenged as such as long as, the relevant law stipulates (Verwaltungsverfahrensgesetz, para. 46), observance of the relevant procedural rules would not have altered the ultimate decision. Questionable as this is in the light of due process principles as a core element of the rule of law, it again underlines the distance between the ideal-type of Weberian bureaucracy, with its basic idea of formal legality as the exclusive guideline for administrative decision making, and the reality of German public administration, characterized by flexibility and pragmatism.

Last but not least, the idea of bureaucratic professionalism is not fully implemented in German public administration either. Certainly, the corps of well-educated civil servants for different strata and segments of public administration has formed the backbone of German civil service since the late seventeenth century (cf. Wunder 1986). However, the system of the corporation of public law (Körperschaft des öffentlichen Rechts) and the systematic co-optation of its respective clientele into their governing bodies have led to the combination of administration by professionals with administration by amateurs. Nonprofessionals as "members" of corporations of public law have a considerable influence on the actual policy of governmental agencies.

\section{Weberian and Non-Weberian Thought and Its Consequences in a German versus a U.S. Perspective} It has been stated that Max Weber's theory of bureaucracy has gained much more influence in the United States than in its country of origin, Germany (Debbasch 1978, 13). While Weber is treated as the icon of pure theory of public administration in the United States (cf. Suleiman 2006), his name is used as a formal point of reference in German textbooks on public administration at best. There is an overall consensus among German scholars and practitioners that Weber's ideal-typical conception of bureaucracy does not cover the reality of German public administration (cf. Bogumil and Jann 2008; Bogumil, Jann, and Nullmeier 2006). That reality is portrayed in the relevant literature as being shaped by strong cooperative ingredients and pragmatic decision making rather than strict observance of formal legality and related standard operating procedures. Non-Weberian characteristics of public administration are implicitly or explicitly interpreted —or heralded-as progressive or postmodern phenomena relative to the traditional concept of modern administration outlined by Weber. Students of public 
administration outside Germany, by contrast, tend to identify formal legality and hierarchical governance as well as the application of standard operating procedures by unemotional bureaucrats with Weber's concept of a nonpolitical sphere of public administration and with Hegel's notion of the state as the expression of ultimate reason for the sake of the collective good (cf. Lee and Raadschelders 2008, 420-21 [on Hegel and Weber]; Raadschelders 2010; Rutgers 2001; Sager and Rosser 2009), while feeling the necessity to characterize elements of administrative autonomy and flexibility as surprisingly non-German (e.g., Wilson 1989, 14-18).

So what we realize is an intercultural paradox when it comes to the reception of Weberian and non-Weberian thought. While Weber's notion of bureaucracy never became popular in its country of origin, German non-Weberian thought remained virtually unknown outside the country, despite its actual influence on public administration doctrine building. In the transatlantic dimension, especially in a German versus U.S. perspective, a diachronic explanation (Bevir 1999, 221-64) helps us understand that paradox.

The divergent patterns of Weberian and non-Weberian ideas and their respective influence in Germany and the United States are connected to divergent patterns of political and administrative modernization. Since the seventeenth century, state modernization in Germany meant not only to make the state apparatus more efficient, but also to enhance its integrative capacity vis-à-vis challenging groups whose interests were put at risk by the process of modernization. The prototype was the landed aristocracy, whose integration by way of decentralization and co-optation paved the way for an entire pattern of political integration through public administration. This made the notion of a flexible and integrative state apparatus attractive to German theorists and practitioners in a situation in which the integrative forces of political modernization were substantially hampered. After all, full parliamentary government was established in Germany only in 1918. What is more, Germans experienced the blessing of a professional but strongly decentralized and self-governing public administration when the latter secured public order and a minimum of stability in times of severe political crisis or even the collapse of formal statehood, as was the case during the immediate postwar periods of 1918 and 1945-46.

State modernization in the United States, by contrast, meant early political modernization in the absence of a professional administration (Nelson 1982; Skowronek 1982; Stillman 1990, 1997). This made the notion of an apolitical and efficient public administration attractive to U.S. theorists and practitioners, with Woodrow Wilson's famous paper of 1887 as the most prominent example. Hence the attractiveness and plausibility of Weberian thought in the United States. How to harmonize a strong and self-confident professional bureaucracy with the principles of responsible government, the rule of law, transparency, and accountability thus remained a prominent topic in U.S. administrative science (cf. Finer 1941; Friedrich 1937, 1957, 1960; Selznick 1949).

By the same token, Weber's notion of bureaucracy as an apolitical tool of government never gained full recognition in Germany. On the one hand, Weber just described the overall logic of bureaucracy as the rational instrument of the (monarchical, nondemocratic) government as it had been emerging in most advanced German principalities in kingdoms since the seventeenth century. On the other hand, he conceived the ideal-type of modern bureaucracy as an integral part of an all-encompassing process of rationalization, pertaining to worldviews, the economy, and the organization of statehood. These analyses were of limited practical relevance for those who, at the time of Weber's writings, had been successful in efficiently running a modern bureaucracy for 200 years, namely, the cast of bureaucrats itself. Weber's ideal-typical concept of modern bureaucracy never gained influence in the discipline that actually shaped doctrine building in German administrative science most: public law jurisprudence.

Thus, it was because of the practical process of state building in terms of modern bureaucracy that German administrative science emerged without a theoretical "grand design" of some influence. While Weber's theory of an apolitical bureaucracy seemed to be inappropriate given the actual political history of public administration, the contributions of his more realistic theoretical contenders were not remotely as systematic and coherent as Weber's concept of bureaucracy as integral part of an epochal process of rationalization. Both the eighteenth-century Polizeywissenschaft (cf. Maier 1966) and the voluminous Verwaltungslehre of Lorenz von Stein, written in second half of the nineteenth century, remained "good practice" guidelines for the various fields of public administration. Weber's concept of bureaucracy, by contrast, gained attraction primarily among sociologists and political scientists who were more interested in the abstract characteristics of public administration than in making bureaucracy work. However, the influence of Hegel might have been attributable to the fact that his notion of the state as the ultimate materialization of reason not only elevated the self-esteem of those running the state, but also, at the same time, was abstract enough not to collide with the actual practice of public administration in Germany.

It is here that the roots of non-Weberian thought and its influence in German administrative science are located. The gap between the abstract Hegelian notion of the state as the guarantor of reason and Weber's abstract notion of bureaucracy as the apolitical tool of government and the actual practice of bureaucracy as it had emerged in Germany since the seventeenth century was partly bridged by the contributions to administrative science delivered by Lorenz von Stein, Otto Hintze, and Rudolf Smend. Their ideas had the common denominator that the reason of the state in the Hegelian sense did not necessarily imply the existence of a unified, coherent, hierarchically structured bureaucracy, exclusively guided by formal legality and run by professional staff. Lorenz von Stein referred to public administration as the "working state," embedded in civil society and responding to the actual needs of the citizens. Otto Hintze, the most prolific analyst of the integrative power of public administration in Prussia, described the logic of co-optation and cooperation that linked the power and the interests of the Crown and the landed aristocracy as a challenging societal group shaping both the organizational structure and the style of state-society interaction. Rudolf Smend gave a justification of the integrative activity of the entire state machinery, including public administration, as opposed to the notion of bureaucracy as merely executing the rule of law.

By contrast, the notion of a nonhierarchical, nonlegalistic, semiprofessional, decentralized, and adaptive public administration, 
prone to building compromises and cooperative relationships with societal groups, was the opposite of what reform-minded theorists in the United States such as Woodrow Wilson were aiming for at the end of the nineteenth century. What made the thoughts of Wilson so Hegelian in style and appropriate as a doctrine for the early Progressive Era was precisely what made it "Weberian" in the sense of advocating for public administration as an apolitical and efficient organization run by well-educated and nonpartisan professionals. Not only did non-Weberian thought of German origin remain virtually unknown in the United States, but also empirical deviations from Weber's ideal-type of bureaucracy were evaluated much more skeptically than in Germany. In the Wilsonian tradition, U.S. administrative science stressed the notion of bureaucracy as an integral part of democratic-hence responsible-government (Friedrich $1937,1957)$ and the professionalism as well as ethical responsibility of the individual civil servant (Finer 1941; Mosher 1968; Wilson 1989, 1993).

No such strand of normative literature on public administration emerged in Germany once democracy was firmly established in the Western part of the country after World War II. Issues of accountability and administrative responsibility play a minor role in German public opinion and administrative science. The same holds true for the actual quality and enforcement of civil and human rights. When administrative science (Verwaltungswissenschaft) reemerged during the 1960s in what was then the West German Federal Republic, it was, characteristically enough, directed against the notion of public administration as the rational instrument of formal legality. Theoretical and conceptual components of U.S. organization theory, policy science, and administrative and legislative practice were selectively adapted in accordance with what was compatible with German public administration practice and its implicit nonWeberian tradition. Niklas Luhmann $(1964,1966)$, who started his career as a civil servant in the state administration of Lower Saxony, adapted the bounded rationality-approach of the Carnegie School of Management (Herbert A. Simon, James G. March) in an attempt to conceptualize modern public administration as it was shaped by the contrast of formal versus informal organizational structures and the quest for decision making under the condition of limited rationality. Fritz W. Scharpf, in a short but highly influential study with the significant title "The Political Costs of the Rule of Law" (Die politischen Kosten des Rechtsstaats, 1970), which was dedicated to his academic teacher Horst Ehmke (himself a disciple of Rudolf Smend), promoted the idea of emancipating public administration from strict legal ties and delegating regulatory power to decentralized administrative units in an attempt to make the latter more effective and more democratic - that is, more intensively controlled at the local level—at the same time.

This tone set, deviations from the legally bounded and hierarchically guided bureaucracy have been appraised in (West) German administrative science as elements of organizational flexibility and ingredients of organizational learning (cf. Benz 1994; Mayntz and Derlien 1978; Lehmbruch 1987). Ironically, this reflected the predemocratic legacy of German public administration as a political integrator without addressing it as such. The neglect was Weberianism in a non-Weberian vein: the emphasis was on performance improvement rather than on political integration, thus treating public administration as a tool of government, just as it had been treated by Weber.
Focusing on performance alone implied a one-sided perspective on public administration that took into consideration neither its actual role as political integrator nor the risks of non-Weberian bureaucracy with respect to normative democratic standards.

This is again revealed by a German-U.S. comparison. U.S. administrative science reflects the traditional American skepticism vis-à-vis government agencies being compromised by pressure groups at the expense of the rule of law, the will of elected legislators, and the overall public interest, as may be illustrated by a brief series of related examples. The co-optation of challenging groups-as we saw, a dominant pattern of governance in German public administration since the seventeenth and eighteenth centuries-is perceived in the United States as an illegitimate threat to the principle of responsible government and accountable administration. The school-building message of Philip Selznick's TVA and the Grass Roots (1949) was that the co-optation of challenging societal groups inevitably leads to goal deflection and violation of the principles of responsible government and accountable administration. It was only in the context of "gender mainstreaming" and "diversity management" in the $1990 \mathrm{~s}$ that J. Donald Kingsley's idea of "representative bureaucracy"- the British version of "integration by administration," German style - gained some influence in the United States (cf. Selden 1997). The German version of "representative bureaucracy," however, is restricted to the acknowledgment of the influence of well-organized groups such as the unions, peak associations, and organized business, while the integration of minorities through systematic co-optation remained a blind spot in both German administrative science doctrine building and administrative practice. ${ }^{10}$

Similarly, the evaluation of interagency and state-citizen cooperation remained different in German and U.S. administrative science. A telling example is the assessment of public policy implementation that formed a major strand of administrative science research in 1970s. In their seminal study, Pressman and Wildavsky (1973) developed an early version of a "veto player" analysis that identified the multiplicity of public agencies and private stakeholders participating in the implementation of public policy programs as the main factor that doomed those programs to fail. Conversely, mainstream implementation research in Germany characterized potential veto points and interagency or state-business negotiations as components of an adaptive learning circle, and thus elements of administrative elasticity (Mayntz 1980, 1983). The question of legitimate and illegitimate influence on public administration decision making and the selection bias of public-private bargaining (or "partnership") remained unaddressed. While antibureaucratic sentiments in the United States, as a rule, express a basic democratic reflex that restricts government interference, antibureaucratic thoughts in Germany express a spirit of cooperative-style state-society interaction and informal decision making rooted in the predemocratic political history of the country and, thus, prone to neglect democratic standards of transparency and control.

Accordingly, it does not come as a surprise that the influence of German administrative science remained limited in the post-World War II era. The dominant topic of scholarly debate in the field since the 1960s - the structural conservatism of public administration and the necessity of administrative reform (Mayntz and Scharpf 1973; Scharpf 1973)—had prominent forerunners in other 
countries, especially in France (Crozier 1963, 1971). It became even more parochial when it focused, from the mid-1970s on, on the idiosyncrasies of German federalism known as the "joint decision trap" (Politikverflechtung; see Scharpf 1988; Scharpf, Reissert, and Schnabel 1976), while further generalizations in a game theoretical vein (cf. Scharpf 1997) were soon to be eclipsed by the resounding success of the veto player theorem (Tsebelis 2002).

\section{Conclusion: Integration through Administration as a Paradigm of Mutual Learning}

The puzzle connected to the notion of public administration as a political integrator is that it does not conform to the standard model of democratic integration through parties, civil society, and parliaments. The kind of non-Weberian thought portrayed in the present paper supports rather than mitigates this skepticism. What made the works of Lorenz von Stein, Otto Hintze, and Rudolf Smend influential and undertheorized at the same time was that they aptly reflected the delayed political modernization of German statehood, with full parliamentary government occurring only in 1918 . Political integration through public administration, established in the seventeenth century as a compromise between the Crown and the landed nobility, remained a functional equivalent to parliamentarization and full civic emancipation in Germany throughout the nineteenth century. Therefore, it had no counterpart in the doctrine building of classic democracies, including the United States, and it became useless in Germany as a normative concept after World War II without losing its implicit influence. However, there are lessons to be learned from both an analytic and a normative perspective.

From an analytic perspective, the mechanisms through which organizational bodies in the public realm mobilize the support of their sociopolitical environment are of particular interest. While the traditional perspective (Easton 1965) is restricted to the distinction of input- versus output-stimulated support (which would leave to public administration just the role of an efficient output provider in a Weberian sense), the importance of office-level participation and co-optation or the role of sense making and identity patterns for the local support of public authorities is largely underresearched. The notion of public administration as the "working state" (Stein), the German experience of co-opting challenging groups into administrative bodies as described by Otto Hintze, and Smend's "integration doctrine" emphasizing the role of the "spirit of the public" as a driving force of state practice provide a helpful stimulus for related research efforts. Instead of discarding these ideas as predemocratic, one might address the dilemmas of democratic integration revealed by their application to present-day administration.

From a normative perspective, one of those dilemmas is the potential conflict between standards of democratic transparency, control, and accountability versus the representation of challenging groups and/or minorities in public agencies. Western Democracies obviously handle the dilemma differently. While the U.S. school of thought is driven by a concern for protecting public authorities against the illegitimate influence of particularistic pressure

groups while tolerating the notion of "representative bureaucracy" to the extent that public administration should reflect the ethnic diversity of society, the German pattern is diametrically opposed. It is an empirical question, however, if and to what extent the selective inclusion of powerful groups or "veto players" reduces standards of due process and transparency and to what extent ethnic selectivity in civil service recruitment reduces rule of law standards when it comes to sensitive branches of the public service, such as immigration authorities or police forces. As recent U.S. history demonstrates, the quality of civil rights and the effectiveness of civil rights protection may depend as much on the representation of minorities in public administration as on legislation and the rulings of courts. As recent German history demonstrates, the inclusion of well-represented challenging groups in public administration decision-making bodies may not be enough to exploit the integrative capacity of the state.

\section{Notes}

1. In the Continental European use, "state" refers to the entirety of government, administration, and the judiciary, while Americans will spontaneously associate the term "state" with a subdivision of government. The language of "Bringing the State Back In" used by political scientists and sociologists in the $1980 \mathrm{~s}$ (Evans, Rueschemeyer, and Skocpol 1985) did not alter these terminological conventions very much, but it stimulated research on the historical sociology of government and administration, very much in the tradition of Otto Hintze (cf. Ertman 1997 as a prominent example).

2. "Herrschaft ist am Alltag primär: Verwaltung" (To rule in every day life means primarily: administration) (Weber 1922, 126).

3. "Die rein bureaukratische, also: die bureaukratisch-monokratische aktenmäßige Verwaltung ist nach allen Erfahrungen die an Präzision, Stetigkeit, Disziplin, Straffheit und Verläßlichkeit, also: Berechenbarkeit für den Herrn wie für die Interessenten, Intensität und Extensität der Leistung, formal universeller Anwendbarkeit auf alle Aufgaben, rein technisch zum Höchstmaß der Leistung vervollkommenbare, in all diesen Bedeutungen: formal rationalste, Form der Herrschaftsausübung" (The purely bureaucratic, thus bureaucratic-monocratic document-based administration is, according to all experience, with respect to precision, steadiness, discipline, tightness, reliability, thus predictability for the chief as well as for the client, intensity and extensity of performance, formally universal applicability to any kind of tasks, technically to the highest degree of performance improvable, in all the variety of these meanings formally most rational type of authority] (Weber 1922, 128).

4. cf. Stolleis: "In the sober perspective of its utility for everyday administration [Von Stein's concept of public administration] is barely more than a pompous ruin" $(1992,391)$.

While the U.S. school of thought is rather driven by a concern for protecting public authorities against the illegitimate influence of particularistic pressure groups while tolerating the notion of "representative bureaucracy" to the extent that public administration should reflect the ethnic diversity of society, the German pattern is diametrically opposed.
5. The three core mechanisms of integration, according to Smend, are personal, functional, and factual integration. "Functional" integration mainly translated into integration through institutions while, "factual" integration was used by Smend as a synonym for integration through public goods and services. Kelsen (1930) criticized Smend for implicit anti-Semitism because he cited affirmatively a casual remark of Max Weber (!) who "apparently" had the sense of Jews from Eastern Europe (Ostjuden) as "impossible Leaders of a German governmental life, even in times of revolution" which Smend took as an indication that there are "persons who, according to their nature (Wesen) are not capable to fulfill integrative functions" (Kelsen 1930, 29).

6. For an overview, see Meinck (1978) and Stolleis (1974; 1999, 316-400). 
7. This was made explicit in some exemplary cases, such as the tax law. An informative example is paragraph 1 of the Steueranpassungsgesetz (tax amendment law) of 1934, which read, "The tax laws have to be applied in accordance with the national-socialist world view (Weltanschaunng)" (Steueranpassungsgesetz, October 16, 1934, Reichsgesetzblatt I, 929).

8. Horst Ehmke, professor of law at the University of Freiburg, became state secretary (administrative department head) in the Federal Department of Justice in 1966. He served for a couple months as minister of justice in 1969 before he was appointed chief of staff of the Federal Chancellery under Willy Brandt (1969-74), becoming one of the most powerful figures in the federal government. Roman Herzog, at the time a professor of law in the Graduate School of Administrative Science in Speyer and temporarily its rector (president), was president of the Federal Republic of Germany from 1994 to 1999.

9. This was precisely how a direct disciple of Smend, Horst Ehmke, would present the usefulness of indefinite legal terms and general clauses in the early $1960 \mathrm{~s}$ (Ehmke 1960, 1963). On Ehmke's political role in post-World War II West German history, see note 8 herein.

10. On the selectivity of interest groups representation in German public policy making, see Offe (1972).

\section{References}

Badura, Peter. 1977. Staat, Recht und Verfassung in der Integrationslehre. Zum Tode von Rudolf Smend (15. Jannuar 1882-5. Juli 1975). Der Staat 15: 305-25.

Benz, Arthur. 1994. Kooperative Verwaltung. Funktionen, Voraussetzungen und Folgen. Baden-Baden: Nomos Verlagsgesellschaft.

Bevir, Mark. 1999. The Logic of the History of Ideas. Cambridge: Cambridge University Press.

Blasius, Dirk, and Eckart Pankoke. 1977. Lorenz von Stein. Geschichts- und gesellschaftswissenschaftliche Perspektiven. Darmstadt: Wissenschaftliche Buchgesellschaft.

Bogumil, Jörg, and Werner Jann. 2008. Verwaltung und Verwaltungswissenschaft in Deutschland. Einführung in die Verwaltungswissenschaft. 2nd ed. Wiesbaden: VS Verlag für Sozialwissenschaften.

Bogumil, Jörg, Werner Jann, and Frank Nullmeier, eds. 2006. Politik und Verwaltung. Politische Vierteljahresschrift. Special issue 37. Wiesbaden: VS Verlag für Sozialwissenschaften.

Clark, Christopher. 2006. Iron Kingdom: The Rise and the Downfall of Prussia, 1600-1947. London: Penguin.

Crozier, Michel. 1963. Le phénomène bureaucratique. Paris: Le Seuil. - 1971. La société bloquée. Paris: Le Seuil.

Debbasch, Charles. 1978. La science administrative dans les pays de l'Europe occidentale. International Review of Administrative Science 44: 12-27.

Downs, Anthony. 1967. Inside Bureaucracy. Boston: Little, Brown.

Easton, David. 1965. A Systems Analysis of Political Life. Chicago: University of Chicago Press.

Ehmke, Horst. 1960. "Ermessen" und "unbestimmte Rechtsbegriffe" im Verwaltungsrecht. Tübingen: J. C. B. Mohr (Paul Siebeck).

-1963. Prinzipien der Verfassungsinterpretation. Veröffentlichungen der Vereinigung der Deutschen Staatsrechtslehrer 20. Berlin: Duncker \& Humblot.

Ellwein, Thomas. 1993. Der Staat als Zufall und Notwendigkeit. Vol. 2, Die öffentliche Verwaltung im gesellschaftlichen und politischen Wandel 1919-1990. Opladen: Westdeutscher Verlag.

Ertman, Thomas. 1997. Birth of the Leviathan: Building States and Regimes in Medieval and Early Modern Europe. Cambridge: Cambridge University Press.

Evans, Peter B., Dietrich Rueschemeyer, and Theda Skocpol, eds. 1985. Bringing the State Back In. Cambridge: Cambridge University Press.

Finer, Herman. 1941. Administrative Responsibility in Democratic Government. Public Administration Review 1(4): 335-50.
Friedrich, Carl J. 1937. Constitutional Government and Politics: Nature and Development. New York: Harper \& Brothers.

- 1957. Constitutional Reason of State: The Survival of the Constitutional Order. Providence, RI: Brown University Press.

—, ed. 1960. Nomos III: Responsibility. New York: Liberal Arts Press.

Gilbert, Felix, ed. 1975. The Historical Essays of Otto Hintze. Oxford: Oxford University Press.

Hedemann, Justus W. 1933. Die Flucht in die Generalklausel. Eine Gefahr für Staat und Recht. Tübingen: J. C. B. Mohr (Paul Siebeck).

Hegel, Georg W. F. 1821. Grundlinien der Philosophie des Rechts. In Werke, by Georg Wilhelm Friedrich Hegel, vol. 7. Frankfurt am Main: Suhrkamp, 1970.

Herzog, Roman. 1970. Verwaltung und Verwaltungsrecht in einer freiheitlichen Industriegesellschaft. Festvortrag vor 48. Deutschen Juristentag in Mainz. Vol. II, Part L.

Hintze, Otto. 1896. Preußische Reformbestrebungen vor 1806. In Otto HintzeGeist und Epochen der der preußischen Geschichte. Gesammelte Abhandlungen, edited by F. Hartung, 537-62. Leipzig: Koehler \& Amelang, 1943.

. 1906. Hof- und Landesverwaltung in der Mark Brandenburg unter Joachim II. In Otto Hintze-Geist und Epochen der der preußischen Geschichte. Gesammelte Abhandlungen, edited by F. Hartung, 238-88. Leipzig: Koehler \& Amelang, 1943. - 1908. Der preußische Militär- und Beamtenstaat im 18. Jahrhundert. In Otto Hintze-Geist und Epochen der der preußischen Geschichte. Gesammelte Abhandlungen, edited by F. Hartung, 453-62. Leipzig: Koehler \& Amelang, 1943. - 1911. Der Beamtenstand. In Otto Hintze-Soziologie und Geschichte. Gesammelte Abhandlungen zur Soziologie, Politik und Theorie der Geschichte, edited by G. Oesterreich, 66-125. Göttingen: Vandenhoeck \& Ruprecht, 1964.

- 1913. Die Hohenzollern und der Adel. In Otto Hintze-Geist und Epochen der preußischen Geschichte. Gesammelte Abhandlungen, edited by F. Hartung, 38-63. Leipzig: Koehler \& Amelang, 1943.

1915. Die Hohenzollern und der Adel. In Otto Hintze-Geist und Epochen der preußischen Geschichte. Gesammelte Abhandlungen, edited by F. Hartung, 172-237. Leipzig: Koehler \& Amelang, 1943.

- 1927. Der Staat als Betrieb und die Verfassungsreform. In Otto HintzeSoziologie und Geschichte. Gesammelte Abhandlungen zur Soziologie, Politik und Theorie der Geschichte, edited by G. Oesterreich, 205-9. Göttingen: Vandenhoeck \& Ruprecht, 1964.

Kelsen, Hans. 1930. Der Staat als Integration. Eine prinzipielle Auseinandersetzung. Berlin: Julius Springer.

Kingsley, J. Donald. 1944. Representative Bureaucracy: An Interpretation of the British Civil Service. Yellow Spring, OH: Antioch Press.

Kocka, Jürgen. 1981. Otto Hintze, Max Weber und das Problem der Bürokratie. Historische Zeitschrift 233: 65-105.

Koselleck, Reinhart. 1967. Preußen zwischen Reform und Revolution. Allgemeines Landrecht, Verwaltung und soziale Bewegung von 1791-1849. Stuttgart: Ernst Klett Verlag.

Lee, Kwang-Hoon, and Jos C. N. Raadschelders. 2008. Political-Administrative Relations: Impact of and Puzzles in Aberbach, Putnam, and Rockman, 1981. Governance 21(3): 419-38.

Lehmbruch, Gerhart. 1987. Administrative Interessenvermittlung. In Verwaltung und ihre Umwelt. Festschrift fir Thomas Ellwein, edited by Adriennne WindhoffHéritier, 11-43. Wiesbaden: Westdeutscher Verlag.

Lhotta, Roland, ed. 2005. Die Integration des modernen Staates. Zur Aktualität der Integrationslehre von Rudolf Smend. Baden-Baden: Nomos Verlagsgesellschaft.

Luhman, Niklas. 1964. Funktionen und Folgen formaler Organisation. Berlin: Duncker \& Humblot.

- 1966. Theorie der Verwaltungswissenschaft. Bestandsaufnahme und Entwurf. Berlin: Grote.

Maier, Hans. 1966. Die ältere deutsche Staats- und Verwaltungslehre. Munich: C. H. Beck. 
Martens, Wolfgang, Peter Häberle, Otto Bachof, and Winfried Brohm. 1972. Grundrechte in Leistungstaat. Die Dogmatik des Verwaltungsrechts vor den Gegenwartsaufgaben der Vervaltung. Veröffentlichungen der Vereiningung der deutschen Staatsrechtslehre 30. Berlin: Duncker \& Humblot.

Mayntz, Renate. 1965. Max Webers Idealtypus der Bürokratie und die Organisationssoziologie. In Bürokratische Organisation, edited by Renate Mayntz, 27-35. Berlin: Kiepenheuer \& Witsch.

—, ed. 1980. Implementation politischer Programme. Empirische Forschungsberichte. Königstein: Verlagsgruppe Athenäum, Hain, Scriptor, Hanstein.

- ed. 1983. Implementation politischer Programme II. Ansätze zur Theoriebildung. Opladen: Westdeutscher Verlag.

Mayntz, Renate, and Hans-Ulrich Derlien. 1978. Vollzugsprobleme der Umweltpolitik. Empirische Untersuchung der Implementation von Gesetzen in Bereich der Luftreinhaltung und des Gewässerschutzes. Stuttgart: Kohlhammer.

Mayntz, Renate, and Jochen Hucke. 1978. Gesetzesvollzug im Umweltschutz. Wirksamkeit und Probleme. Zeitschrift für Umweltpolitik 1: 217-44.

Mayntz, Renate, and Fritz. W. Scharpf. 1973. Planungsorganisation. Die Diskussion um die Reform von Regierung und Veruvaltung des Bundes. Munich: Piper.

Meinck, Jürgen. 1978. Weimarer Staatslehre und Nationalsozialismus. Eine Studie zum Problem der Kontinuität im staatsrechtlichem Denken in Deutschland 1928-1933.

New York: Campus.

Mosher, Frederick C. 1968. Democracy and the Public Service. Oxford: Oxford University Press.

Nelson, Michael. 1982. A Short Ironic History of American National Bureaucracy. Journal of Politics 44(3): 747-78.

Niskanen, William A., Jr. 1971. Bureaucracy and Representative Government. Edison, NJ: Transaction.

Offe, Claus. 1972. Politische Herrschaft und Klassenstrukturen. Zur Analyse spätkapitalistischer Gesellschaftssysteme. In Politikwissenschaft. Eine Einführung in ihre Probleme, 4th ed., edited by Gisela Kress and Dieter Senghaas, 135-64. Frankfurt am Main: Fischer Verlag.

Ossenbühl, Fritz. 1978. Die Quellen des Verwaltungsrechts. In Allgemeines Vertwaltungsrecht, 3rd ed., edited by H. U. Erichsen and W. Martens, 55-118. Berlin and New York: Walter de Gruyter.

Page, Edward C. 1990. The Political Origins of Self-Government and Bureaucracy: Otto Hintze's Conceptual Map of Europe. Political Studies 38(1): 39-55.

Peters, Hans. 1965. Die Verwaltung als eigenständige Staatsgewalt. Krefeld: Scherpen.

Pressmann, Jeffrey L., and Aaron B. Wildavsky. 1973. Implementation: How Great Expectations in Washington Are Dashed in Oakland. Berkeley: University of California Press. Raadschelders, Jos C. N. 2010. Did Max Weber's Agony and Ecstasy Influence His Professional Life?” Public Administration Review 70(2): $304-16$.

Risse-Kappen, Thomas. 1994. Ideas Do Not Float Freely: Transnational Coalitions, Domestic Structures, and the End of the Cold War. International Organization 48(2): 185-214. Rutgers, Mark R. 2001. Traditional Flavors? the Different Sentiments in European and American Administrative Thought. Administration \& Society 33(2): 220-40.

Rüthers, Bernd. 1968. Die unbegrenzte Auslegung. Zum Wandel der Privatrechtsordnung im Nationalsozialismus. Tübingen: J. C. B. Mohr (Paul Siebeck).

Sager, Fritz, and Christian Rosser. 2009. Weber, Wilson and Hegel: Theories of Modern Bureaucracy. Public Administration Review 69(6): $1136-47$.

Scharpf, Fritz W. 1970. Die politischen Kosten des Rechtsstaats. Eine vergleichende Studie der deutschen und amerikanischen Verwaltungskontrollen. Tübingen: J. C. B. Mohr.

- 1973. Planung als politischer Prozess. Aufsätze zur Theorie der planenden Demokratie. Frankfurt am Main: Suhrkamp.

1988. The Joint-Decision Trap: Lessons from German Federalism and European Integration. Public Administration 66(2): 239-78.

1997. Games Real Actors Play: Actor-Centered Institutionalism in Policy Research. Boulder, CO: Westview Press.

Scharpf, Fritz W., Bernd Reissert, and Fritz Schnabel. 1976. Politikverflechtung. Theorie und Empirie des kooperativen Föderalismus in der Bundesrepublik. Kronberg: Scriptor.

Scheuner, Ulrich. 1977. Zur Rolle der Verbände im Rahmen der sozialen Verwaltung nach der Lehre von Lorenz von Stein. Die Stellung Lorenz von Steins in der neuerem

Staats- und Gesellschaftslehre. In Staat und Gesellschaft. Studien ïber Lorenz von Stein, edited by R. Schnur, 273-304. Berlin: Duncker \& Humblot.

Seibel, Wolfgang. 1996. Administrative Science as Reform: German Public Administration. Public Administration Review 56(1): 74-81.

Selden, Sally Coleman. 1997. The Promise of Representative Bureaucracy: Diversity and Responsiveness in a Government Agency. Armonk, NY: M. E. Sharpe.

Selznick, Philip. 1949. TVA and the Grass Roots: A Study in the Sociology of Formal Organization. Berkeley: University of California Press.

Skocpol, Theda. 1979. States and Social Revolutions: A Comparative Analysis of France, Russia, and China. Cambridge: Cambridge University Press.

Skowronek, Stephen. 1982. Building a New American State: The Expansion of National Administrative Capacities 1877-1920. Cambridge: Cambridge University Press.

Smend, Rudolf. 1923. Die politische Gewalt im Verfassungsstaat und das Problem der Staatsform. Reprint of Staatsrechtliche Abhandlungen, Berlin: Duncker \& Humblot, 1968. 1928. Verfassung und Verfassungsrecht. Berlin: Duncker \& Humblot.

Stein, Lorenz von. 1865. Verwaltungslehre und Verwaltungsrecht. Frankfurt am Main: Vittorio Klostermann, 1958.

- 1866-84. Handbuch der Verwaltungslehre. 8 Vols. Stuttgart: Cotta.

Stillman, Richard J., II. 1990. The Peculiar "Stateless" Origins of American Public Administration and the Consequences for Government Today. Public Administration Review 50(2): 156-65.

1997. American vs. European Public Administration: Does Public Administration Make the Modern State, or Does the State Make Public Administration? Public

Administration Review 57(4): 332-38.

Stolleis, Michael. 1974. Gemeinwohlformel im nationalsozialistischen Recht. Berlin: J. Scheitzer Verlag.

1992. Geschichte des Öffentlichen Rechts in Deutschland. Vol. 2, Staatsrechtslehre und Verwaltungswissenschaft 1800-1914. Munich: C. H. Beck.

1999. Geschichte des Öffentlichen Rechts in Deutschland. Vol. 3, Staats- und Verwaltungsrechtswissenschaft in Republik und Diktatur 1914-1945. Munich: C. H. Beck.

Suleiman, Ezra. 2006. Is Weber Still Relevant? The Future of Bureaucracy: Speech in Honor of Juan Linz. http://www.docstoc.com/docs/2458577/IS-WEBER-STILL-

RELEVANT-The-Future-of-Bureaucracy [accessed June 14, 2010].

Tsebelis, George. 2002. Veto Players: How Political Institutions Work. Princeton, NJ: Princeton University Press.

Waldo, Dwight. 1961. Organizational Theory: An Elephantine Problem. Public Administration Review 21(4): 210-25.

Weber, Max. 1922. Wirtschaft und Gesellschaft. Grundriß der verstehenden Soziologie. Tübingen: J. C. B. Mohr (Paul Siebeck), 1976.

Wilson, James Q. 1989. Bureaucracy: What Government Agencies Do and Why They Do It. New York: Basic Books.

1993. The Moral Sense. New York: The Free Press.

Wilson, Woodrow. 1887. The Study of Administration. Political Science Quarterly 2(2): 197-222.

Wunder, Bernd. 1986. Geschichte der Bürokratie in Deutschland. Frankfurt am Main: Suhrkamp. 